\title{
Skorið inn að kviku
}

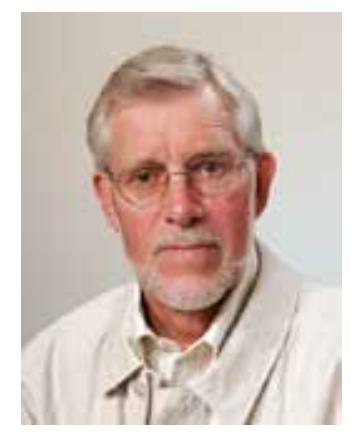

Gísli G. Auðunsson heimilislæknir á Húsavík

Gisli@heilhus.is

Gísli starfaði i áratugi við Heilsugæslustöðina og Sjúkrahúsið á Húsavík. Hann er sérfræđingur í heimilislækningum og með meistaragráđu í peirri grein frá University of Western Ontario, Kanada. Hann er nú hættur föstu starfi sakir aldurs.

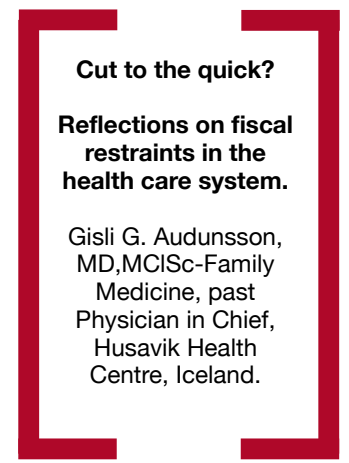

Frumvarp til fjárlaga, sem lagt var fram á Alpingi í byrjun október, hefur valdið ótta og reiði í fjölmörgum byggðarlögum landsins. Svo mikilli reiði að peir sem lengi hafa fylgst með, muna ekki eftir annarri eins mótmælaöldu. Hvað veldur? Fjárlagafrumvarpið gerir ráð fyrir gríðarlegum niðurskurði til flestra sjúkrahúsa á landsbyggðinni og auk pess til framhaldsskólanna. Parna er komið við kvikuna - alveg inn að kviku. Fólk polir margvíslegt mótlæti en pegar ýmist á að rústa eða draga allan mátt úr peim stofnunum sem standa peim næst, sem veita peim öryggi, er peim nóg boðið. Par liggja mörkin.

Ríkisstjórn Íslands stendur frammi fyrir miklum vanda. Hún boðaði mikinn niðurskurð en tók pó fram að heilbrigðismálum og menntamálum yrði hlifft, par yrði niðurskurðurinn minni. En hvað kom fyrir fjárlagagerðarmenn? Нvað varð til pess að boðaður 5\% niðurskurður varð allt í einu að tæplega 40\% niðurskurði á sumum heilbrigðisstofnunum? Urðu peir fyrir vitrun? Tæpast. Hins vegar barst peim rödd úr ráðuneyti heilbrigðismála, bergmál af endurtekinni pulu kenningasmiða sem hæstráðendurheilbrigðismála hafa lengi hlustað á og virðast nú trúa á. Í pulunni segir að litlu sjúkrahúsin á landsbyggðinni séu úreltar stofnanir sem beri að leggja niður. Pær veiti ekki nógu góða pjónustu, en landsmenn eigi kröfu til bestu heilbrigðispjónustu og hana sé aðeins hægt að veita á hátæknisjúkrahúsunum. Petta er auðvitað rétt í peim tilvikum sem hátæknin á við, en fjarri fer pví að hún eigi alltaf við. Og pví miður hafa margir málsmetandi menn í læknastétt, sem starfa á pröngum sérsviðum, tileinkað sér petta viðhorf og haldið pví á lofti.

Sjúkrahúsin á landsbyggðinni starfa samkvæmt lögum um heilbrigðispjónustu nr. 40 frá 27. mars 2007 og reglugerð um heilbrigðisumdæmi, sem sett var samkvæmt peim. Par er talið upp hvar á landinu skuli vera "heilbrigðisstofnanir" og hvaða pjónustu pær eigi að veita. En par segir „,... аð pær veiti almenna heilbrigðispjónustu í umdæminu. Með almennri heilbrigðispjónustu er átt við heilsugæslu, pjónustu og hjúkrun á hjúkrunarheimilum og hjúkrunarrýmum stofnana og almenna sjúkrahúspjónustu." Petta er sú pjónusta sem fjölmargar heilbrigðisstofnanir landsins veita, en sumar hafa ekki bolmagn til pess að veita almenna sjúkrahúspjónustu sakir fámennis byggðarlaganna. Almenn sjúkrahús á landsbyggðinni flokkast undir pað sem á alpjóðamálinu kallast „Primary Care Hospitals". Sérgreinasjúkrahús, eins og Sjúkrahúsið á Akureyri mundi flokkast undir „Secondary Care Hospital“ og Háskólaspítalinn, Landspítalinn, mundi flokkast undir „Tertiary Care Hospital“. Ég pekki engin dæmi pess í heiminum að pjónusta almennra sjúkrahúsa sé dýrari en pjónusta hátæknisjúkrahúsanna. Of langt mál yrði að telja upp hvaða starfsemi fer fram á almennu sjúkrahúsi, en í lögum um heilbrigðispjónustu er hún pannig skilgreind: „Almennar lyflækningar, hjúkrun, slysamóttaka, endurhæfing og nauðsynleg stoðdeildarpjónusta“. Og pað er nákvæmlega pessi pjónusta sem almennu sjúkrahúsin veita. Nokkur blæbrigðamunur er pó á starfseminni og eðlilega er hún meiri í fjölmennum byggðarlögum eins og á Selfossi, í Keflavík og á Akranesi. Auk pess hefur ríkt um pað nokkurs konar pjóðarsátt að sjúkrahúsin á Ísafirði, í Neskaupsstað og Vestmannaeyjum geti tekist á við flóknari viðfangsefni. Pessi sjúkrahús eru í frekar fjölmennum byggðarlögum sem geta einangrast af veðurfarsástæðum. Öryggi íbúanna er í veði. Рað yrði pjóðinni ekki til sóma að skera pau niður við trog. Рað má ekki gerast.

Раð má heldur ekki gerast að læknar leggist í faglegan meting um mikilvægi starfa sinna og stofnana. Sagt er að fólk eigi að fá pá bestu heilbrigðispjónustu sem völ er á. Pá er gjarnan vísað til Landspítala og um leið gefin í skyn vanhæfni minni sjúkrahúsanna. En hvernig stendur á pví að Landspítali sendir fjölmarga Íslendinga til aðgerða erlendis á hverju ári? Раð er vegna pess að spítalinn býr ekki við sömu pekkingu eða tækni og er til staðar erlendis. Læknar Landspítala senda pví sjúklingana frá sér á betur búnar stofnanir. Раð pýðir ekki að við eigum að leggja niður Landspítalann, heldur eigum við að hlúa að honum á allan hátt og reyna að efla hann sem hátæknisjúkrahús okkar Íslendinga. Og pað sama á við litlu sjúkrahúsin á landsbyggðinni, pau keppa ekki við Landspítala eða Sjúkrahúsið á Akureyri. En par eins og á Landspítala er vel menntað heilbrigðisstarfsfólk sem pekkir takmörk sín og sendir alla pá sjúklinga sem betur eru komnir á stærri sjúkrahúsunum til meðferðar par. Pessi sjúkrahús eru jafn mikilvæg litlu byggðarlögunum hringinn í kringum landið eins og Landspítalinn er landinu öllu. Pví skulum við ekki gleyma. Stöndum saman og verjum alla heilbrigðispjónustu í landinu. 